The Experience of Managing 


\title{
The Experience of Managing
}

\author{
A Skills Guide
}

Chris Clegg, Karen Legge and Sue Walsh

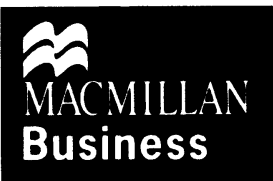


Editorial and selection $\mathbb{C}$ Chris Clegg, Karen Legge and Sue Walsh 1999

Individual chapters (C) individual contributors 1999

All rights reserved. No reproduction, copy or transmission of this publication may be made without written permission.

No paragraph of this publication may be reproduced, copied or transmitted save with written permission or in accordance with the provisions of the Copyright, Designs and Patents Act 1988, or under the terms of any licence permitting limited copying issued by the Copyright Licensing Agency, 90 Tottenham Court Road, London W1P 9HE.

Any person who does any unauthorised act in relation to this publication may be liable to criminal prosecution and civil claims for damages.

The authors have asserted their right to be identified as the authors of this work in accordance with the Copyright, Designs and Patents Act 1988.

First published 1999 by

MACMILLAN PRESS LTD

Houndmills, Basingstoke, Hampshire RG21 6XS

and London

Companies and representatives

throughout the world

ISBN 978-0-333-71416-4 ISBN 978-1-349-27328-7 (eBook)

DOI 10.1007/978-1-349-27328-7

A catalogue record for this book is available from the British Library.

This book is printed on paper suitable for recycling and made from fully managed and sustained forest sources.

$\begin{array}{llllllllll}10 & 9 & 8 & 7 & 6 & 5 & 4 & 3 & 2 & 1\end{array}$

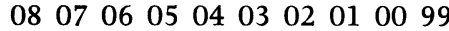

Editing and origination by Aardvark Editorial, Mendham, Suffolk 


\section{Contents}

Introduction

vi

1 Appraisal Dot Griffiths 1

2 Assertion Bryn Davies 9

3 Career Management Sally Maitlis 19

4 Communicating Jean Hartley 31

5 Confrontation Chris Brotherton 39

6 Consulting Binna Kandola 49

7 Counselling John McLeod 66

8 Crisis Management Clare Allen and Morag Maddocks 71

9 Decision Making Chris Clegg $\quad 79$

10 Managing Diversity Catherine Cassell 86

11 Equal Opportunities Janette Webb 95

12 Information Overload Paul Sparrow 111

13 Innovation Nigel King 119

14 Interviewing Carolyn Axtell 128

15 Learning Company Mike Pedler and Kath Aspinwall 141

16 Listening and Questioning A. Lavender and V. Martin 155

17 Meetings Tanya Arroba 161

18 Mentoring Julia Davies 168

19 Negotiating Linda Marsh and Peter Belsey 178

20 Political Skills Heather Höpfl 185

21 Presentation Skills Dot Griffiths 193

22 Project Management Graham M. Winch 204

23 Problem Solving Kevin Gaston and Tudor Rickards 210 
24 Quality Management Patrick Dawson 215

25 Racial Discrimination Bola Fatimilehin 226

26 Sexual Harassment Mandy Wright 236

27 Stakeholder Analysis Karen Legge 242

28 Generating Strategy David Tranfield 249

29 Stress Management Rob Briner $\quad 268$

30 Team Development Sue Walsh 280

31 Time Management Dot Griffiths 285 


\section{Introduction}

This book comprises 31 contributions aimed at developing skills in managing. As such it is principally directed at postgraduate students (for example, those undertaking MBA courses) and participants on post-experience short courses. But, apart from this bald statement, a few words may be useful to clarify our thinking behind this volume.

Some of our readers may be familiar with earlier collections of case studies compiled by two of the editors. This is a rather different book, with a different purpose. The earlier collections were case studies in organisational behaviour, information technology and human resource management that aimed to give students practice in using concepts derived from organisational psychology, behaviour and theory as analytical tools to dissect, understand and prescribe for a range of real-life problems. All the case studies were based on empirical research in major UK organisations in public and private, manufacturing and service sectors. The focus of these case studies was largely the identification and analysis of problems and the proposal of strategies and the design of policies and procedures to overcome the problems. Hence the questions in the case studies were of a 'what' and 'why' variety: 'What is the problem?', 'Why has it occurred?', 'What should be done about it?'. What was not highlighted in these cases was the difficult question that bedevils management action: 'How do we implement the proposals in the most effective manner?'. In other words, the focus of analysis here is on managerial processes and style, and the development of skills in achieving effective action. It should be noted at this point that, except where clearly indicated to the contrary, most of the companies and individuals quoted in the case studies are purely fictitious. Any similarity to existing companies or individuals is completely unintentional.

This focus has arisen from the emerging demands of our students over the past 8-10 years. During that period, we have each been active teaching on postgraduate courses in Business Administration, Clinical and Community Psychology and Occupational and Organisation Psychology, as well as on a number of post-experience courses. Increasingly, our experience is that course participants have been seeking more than an understanding of the theories embraced by the various disciplines and their application. They have been asking for experience and practise in the skills that they need and use in their work and wanting to exercise them in well-prepared and 'richly textured' situations. We have chosen to call these 'managing' skills because they contribute to the process of managing, but these skills are not the sole province of managers. Skills in assertion, negotiation, listening and problem solving are just as relevant to people working in professional, specialist or supervisory roles.

We have given the authors of each 'chapter' a clear brief. They were asked to provide some practical exercises that would give the participants experience of developing and using skills in a particular area. The exercises might involve some combination of role plays, case studies, small group exercises, working in pairs, working alone or plenary group 
discussions. Where possible, all the material needed by the participants is present in the chapter, although some supportive reading may help in gaining further benefit from a particular session. The supporting Tutor's Notes are for use by the tutor and offer further detailed information, advice on how to set up the session (including timings) and what usually happens, along with some background theoretical information. The aim is to support the tutor with enough information to set up a lively and stimulating session.

The intention is very much to provide 'hands-on' sets of exercises to enhance an awareness of 'how to do it' issues, the theory behind alternative styles of practice and, most importantly, the experience of enacting simulated day-to-day management skills and activities. Hence we have not attempted to impose, as systematically as in the past, standard sets of headings and labels. Some authors refer to their contribution as a 'chapter', others as a 'case study', 'exercise' or 'role play'. We have decided to celebrate this diversity of language rather than impose editorial fascism! Furthermore, again in contrast to our earlier books of case studies, we have deliberately made no attempt to 'chunk' contributions according to either a model of organisation ('individual', 'group' or 'organisation') or a discipline ('OB', 'IR' or 'HRM') or theme ('Flexibility, quality and HRM in manufacturing' or 'Towards an enterprise culture'). We consider that many management skills, although analytically separable, are in action indivisible. For example, awareness of stakeholders goes hand in hand with negotiating, and negotiating is often part of the decision-making process, which can in turn involve communicating 'good' and 'bad' news. All of these skills are involved in project management - and in managing such apparently diverse activities as dealing with sexual harassment and appraisal. And so on. We consider that management skills should be seen holistically - as all combine elements of analysis, interpretation, reflection, empathy and presentation - so that attempts to slice up what is properly seen as a whole would be inappropriate. Thus contributions are presented in alphabetical order, by topic, and we invite readers to 'pick and mix' their own selection. We envisage that tutors will put together a selection of the material best suited to the needs of their students and the time available. We must confess, however, to some satisfaction that, as a result of our alphabetical ordering, 'appraisal' and 'assertion' skills that are necessary to most effective managerial action, kick off the book!

The people preparing the material have been carefully selected by the editors as experts in their fields. The authors are teachers, researchers, consultants and practitioners of various kinds, with backgrounds in HRM, organisation behaviour, theory and psychology, as well as in clinical and community psychology, reflecting both the backgrounds of the editors and what we see as the community of practice on which a collection such as this should draw and to which it should contribute. Most of the material presented has been used by the authors in 'live' sessions. We know that these sessions work.

One issue with a volume of this kind concerns the 'comprehensiveness' of coverage. We do not claim to have covered every conceivable skill. For example, we have no entries on 'how to manage difficult people', 'how to cope with being bullied', 'managing crosscompany relations' (for example, as in outsourcing), or 'leading and being led'. As with all compilations, this selection reflects our own and our contributors' interests and commitment to write on some issues rather than others. In any case, comprehensive coverage would give rise to an unmanageable length. Perhaps a second volume may enable us to address further needs.

We should be clear what claims we are making for this book. The aim in each case is not to make its users experts in all the fields covered by the book. Instead, we are aiming to 
give participants the experience of using skills and some insights about their personal strengths and weaknesses, upon which they may then wish to act. Almost without exception, the objectives of each chapter are to:

- give an understanding of, and insight into, the skills involved in a particular area

- provide experience of practising those skills

- encourage a critical awareness of some of the complexities involved in the area.

In any case, we anticipate that users will typically have quite different and varied levels of expertise. Our experience is that some members of our groups have had extensive experience of managing meetings, interviewing candidates for jobs or negotiating, while others in the class may have had little or no direct experience in these areas. In practice, of course, the presence in a group of different patterns of expertise represents an important resource to be drawn upon in these sessions.

So here are the contributions. We hope you will enjoy working through them as much as we have enjoyed editing them. 